\title{
A GIANT CROCODILE SKULL FROM CAN THO, NAMED "DAU SAU", REPRESENTS THE LARGEST KNOWN SALTWATER CROCODILE (Crocodylus porosus) EVER REPORTED FROM VIETNAM
}

\author{
Thomas Ziegler, ${ }^{1,2}$, Nguyen Thien Tao ${ }^{3, *}$, Nguyen Trung Minh ${ }^{3}$, \\ Rainier Manalo ${ }^{4}$, Arvin Diesmos ${ }^{5}$, Charlie Manolis ${ }^{6}$ \\ ${ }^{1}$ AG Zoologischer Garten Köln, Riehler Strasse 173, D-50735 Cologne, Germany \\ ${ }^{2}$ Institute of Zoology, University of Cologne, Zülpicher Strasse 47b, \\ D-50674 Cologne, Germany \\ ${ }^{3}$ Vietnam National Museum of Nature, VAST, Vietnam \\ ${ }^{4}$ Crocodylus Porosus Philippines Inc., Pag-asa, Kapalong, Davao Del Norte, Philippines \\ ${ }^{5}$ Philippine National Museum of Natural History, T.F. Valencia Circle, Rizal Park, T.M. \\ Kalaw Avenue, Ermita, 1000 Manila, Philippines \\ ${ }^{6}$ Wildlife Management International, PO Box 530, Karama, NT 0813, Australia
}

Received 4 November 2019, accepted 8 December 2019

\begin{abstract}
We report on a large crocodile skull recovered from a river bank in August 2010 near Dau Sau Bridge, in An Binh, Ninh Kieu District, Can Tho Province, in southern Vietnam. As the skull from Can Tho, named "Dau Sau" herein, is now deposited in the Vietnam National Museum of Nature, Ha Noi, we reinvestigated the circumstances surrounding its discovery and provide exact measurements. Skull length (dorsal mid-point) is $70.7 \mathrm{~cm}$. The morphological features confirm it is from a Saltwater crocodile (Crocodylus porosus), and not a Siamese crocodile (C. siamensis), which historically also occurred throughout the Mekong Delta of Vietnam. Skull measurements are compared with those of other large $C$. porosus skulls for which reliable estimates of total length are available. We also provide measurements of the prepared skull of "Lolong" $(69.8 \mathrm{~cm})$, a $6.17 \mathrm{~m}$ long $C$. porosus captured in the Philippines in 2011. On the basis of known skull length:total length ratios the crocodile from Can Tho is estimated to be 6.3-6.8 m long. The skull of Dau Sau is likely to have been buried for at least 100 years. We discuss the origin of the local name Dau Sau, which has traditional and cultural significance, and provide historical reports of crocodiles in the area. Dau Sau is smaller than the largest known C. porosus skull $(76 \mathrm{~cm})$, but is the largest ever reported from Vietnam, and one of the largest $C$. porosus known.
\end{abstract}

Keywords: Crocodylidae, Mekong delta, morphology, size, “Lolong”, Philippines.

Citation: Ziegler T., Nguyen Thien Tao, Nguyen Trung Minh, Manalo R., Diesmos A., Manolis C., 2019. A giant crocodile skull from Can Tho, named "Dau Sau", represents the largest known saltwater crocodile (Crocodylus porosus) ever reported from Vietnam. Academia Journal of Biology, 41(4): 25-30. https://doi.org/10.15625/2615-9023/v41n4.14581.

*Corresponding author email: taont@ vnmn.vast.vn

(C2019 Vietnam Academy of Science and Technology (VAST) 


\section{INTRODUCTION}

Extant crocodilian species show a wide range of maximum total lengths (TL), and the Saltwater crocodile (Crocodylus porosus) is considered one of the largest, with males exceeding $6 \mathrm{~m}$ TL. However, precise data on exceptionally large crocodile skulls and the individuals from which they were derived (TL, origin, date of acquisition) are usually incomplete (Fukuda et al., 2018).

Saltwater crocodiles have one of the widest geographic distributions of any crocodilian, ranging from eastern India, through Southeast Asia and the Pacific islands, to Australia in the south. In Vietnam, $C$. porosus is considered to have become extinct long ago, through overexploitation for food and skin, and extensive habitat degradation (Webb et al., 2010). The endemic Siamese crocodile (C. siamensis) had suffered a similar fate, but in 2001-2004 a reintroduced population was established in Cat Tien National Park (Polet 2002; Murphy et al., 2004). Few C. porosus are currently held within the 800+ crocodile farms in Vietnam, and hybridization between $C$. porosus, $C$. siamensis and the exotic Cuban crocodile (C. rhombifer) is likely within the captive population (Jelden 2008).

On 31 August 2010, a large crocodile skull was dug up during excavations at a river bank near Dau Sau Bridge (1001'247' N; $\left.105^{\circ} 75^{\prime} 377^{\prime}, \mathrm{E}\right)$, in An Binh, Ninh Kieu District, Can Tho Province, in southern Vietnam. The skull was pulled out at $6 \mathrm{pm}$ by Mr. Tran Van Ut.

Local newspapers reported the skull as being some $90 \mathrm{~cm}$ long, surpassing known size records for $C$. porosus $(76 \mathrm{~cm})$, and even the longest known recent crocodilian skull in existence $(84 \mathrm{~cm})$ - that of a Tomistoma (Tomistoma schlegelii) held in the British Museum of Natural History (Whitaker and Whitaker 2008). The articles also provided estimates of other attributes, such as age (100 years), length (5-6 m), and body weight $(400 \mathrm{~kg})$.
Here, we provide accurate measurements of the Can Tho skull, confirm its identity and derive estimates of the TL of the crocodile from which it came. The skull is now deposited in the Vietnam National Museum of Nature (VNMN) in Ha Noi.

\section{MATERIALS AND METHODS}

The crocodile skull from Can Tho was examined by $\mathrm{T}$. Ziegler at VNMN and the following measurements (after Webb and Messel 1978) were taken using a metal measuring tape. Total skull length was measured to the nearest $\mathrm{mm}$, and all other measurements to the nearest $0.5 \mathrm{~cm}$.

1. Total skull length (TSL): Tip of snout to the median hind edge of the cranial platform. Due to damage to the left premaxillary bone, the "tip" was estimated.

2. Maximum skull width: Measured at the widest point.

3. Cranial platform width: Maximum width of the cranial platform.

4. Cranial platform midpoint width: Narrowest width of the cranial platform (where it is usually concave).

5. Snout-eye length: Tip of snout to anterior edge of orbit.

6. Snout length: Tip of snout to level of anterior edge of orbit, measured along midline of snout.

7. Interocular width: Narrowest distance between orbits.

For comparison, we included the measurements of the skull of 'Lolong' (see table 1), a giant Saltwater crocodile captured in 2011 from Magsagangsang Creek in Agusan Marsh, Agusan del Sur Province, in the southern Island of Mindanao, the Philippines. The skull is at the National Museum of the Philippines in Butuan City, Mindanao, and was examined and measured by R. Manalo.

\section{RESULTS}

The skull from Can Tho, named Dau Sau herein, is in relatively good condition, with the 
only significant damage being the left premaxillary bone of the snout and the right pterygoid (Fig. 1). The two elongate ridges running from the orbits down the upper part of the snout are characteristic of $C$. porosus. In $C$. siamensis the squamosals form a pronounced bony ridge with another ridge (crest) that extends anteriorly between the orbits (Platt et al., 2018). This feature is absent in the skull from Can Tho. In addition, the size of the skull is from a crocodile that well exceeds the TL of C. siamensis, with a maximum TL around 4.0 m (Platt et al., 2018). The skull measurements of Dau Sau are compared with other known large $C$. porosus skulls (table 1) for which reliable estimates of TL are available.

Table 1. Measurements $(\mathrm{cm})$ of Dau Sau, the skull from Can Tho, relative to other large Crocodylus porosus skulls

\begin{tabular}{|l|c|c|c|c|c|c|c|c|}
\hline & $\begin{array}{c}\text { Dau } \\
\text { Sau } \\
\text { Ziegler } \\
\text { et al., } \\
\text { (this } \\
\text { study) }\end{array}$ & $\begin{array}{c}\text { Old } \\
\text { Charlie } \\
\text { Webb and } \\
\text { Messel } \\
(1978)\end{array}$ & $\begin{array}{c}\text { Dhamara } \\
\text { Kar } \\
(2006)\end{array}$ & $\begin{array}{c}\text { Stuart } \\
\text { Manolis } \\
(2006)\end{array}$ & $\begin{array}{c}\text { Lolong } \\
\text { (live } \\
\text { specimen) } \\
\text { Britton et } \\
\text { al., (2012) }\end{array}$ & $\begin{array}{c}\text { Lolong } \\
\text { (skull) } \\
\text { Ziegler et } \\
\text { al., (this } \\
\text { study) }\end{array}$ & $\begin{array}{c}\text { Edgar } \\
\text { Fukuda } \\
\text { et al., } \\
\text { (2018) }\end{array}$ & $\begin{array}{c}\text { Giryu } \\
\text { Fukuda } \\
\text { et al., } \\
(2018)\end{array}$ \\
\hline $\begin{array}{l}\text { Total Skull } \\
\text { Length }\end{array}$ & 70.7 & 66.6 & 68 & 72.8 & - & 69.8 & 70.1 & 70.6 \\
\hline $\begin{array}{l}\text { Total Head } \\
\text { Length }\end{array}$ & - & - & - & - & 70.0 & - & - & - \\
\hline $\begin{array}{l}\text { Maximum } \\
\text { Skull Width }\end{array}$ & 42.0 & 48.0 & 40 & 45.8 & 45.0 & 43.7 & 52.0 & - \\
\hline $\begin{array}{l}\text { Cranial } \\
\text { Platform } \\
\text { Width }\end{array}$ & 22.5 & 23.5 & 18 & 23.0 & 22.8 & 22.8 & 240 & 205 \\
\hline $\begin{array}{l}\text { Cranial } \\
\text { Platform } \\
\begin{array}{l}\text { Midpoint } \\
\text { Width }\end{array}\end{array}$ & 19.0 & 18.9 & 15 & 19.4 & - & - & - & - \\
\hline $\begin{array}{l}\text { Snout-eye } \\
\text { Length }\end{array}$ & 51.0 & 44.3 & 35 & 50.0 & 49.6 & - & - & - \\
\hline $\begin{array}{l}\text { Snout } \\
\text { Length }\end{array}$ & 49.5 & - & - & - & - & 49.2 & - & - \\
\hline $\begin{array}{l}\text { Interocular } \\
\text { Width (cm) }\end{array}$ & 8.0 & 7.5 & 8 & 7.1 & 8.4 & 8.3 & 8.0 & 6.7 \\
\hline $\begin{array}{l}\text { Total } \\
\text { Length }\end{array}$ & $?$ & 615 & 608 & 670 & 617 & - & 670 & - \\
\hline
\end{tabular}

The year in which Dau Sau died and its remains were longed in sediments is unknown. Local residents indicated that crocodiles had not been seen in the region for decades, but the oldest residents (ca. 80 years old) reported anecdotes from their grandparents, about a very large crocodile occurring in that river historically. It is thus considered likely that the skull had been buried underground for over 100 years.

\section{DISCUSSION}

The name "Dau Sau" has many meanings in the local vernacular. In reference to a locality, Dau Sau means "crocodile head", and there exists a number of places named as such, including Dau Sau channel, Dau Sau estuary, or Dau Sau bridge. Traditional beliefs (e.g., Can Tho Online 2010) refer to Dau Sau as "a huge land mass inhabited by few people and where both sides of the river are deserted." It is unknown from where the name "Dau Sau" actually originated, but there is a folk tale about an area of Cai Rang (formerly belonged to Can Tho), that had many crocodiles. According to the folklore, one day, during a traditional wedding ceremony involving boats on this river, a large crocodile 
whipped its tail, flipped a boat, and took the bride away. The groom, anguished and furious, gathered many strong young people to capture the crocodile. After catching the crocodile, the groom cut it into pieces and threw them into the river to satisfy his anger. Wherever a piece of the crocodile was washed up, people named that part of the channel accordingly. The area where the skin was found was named Cái Da (skin), the area where the teeth were found was called Cái Răng (teeth), and the area where the head was found was called Đầu Sấu (crocodile head).

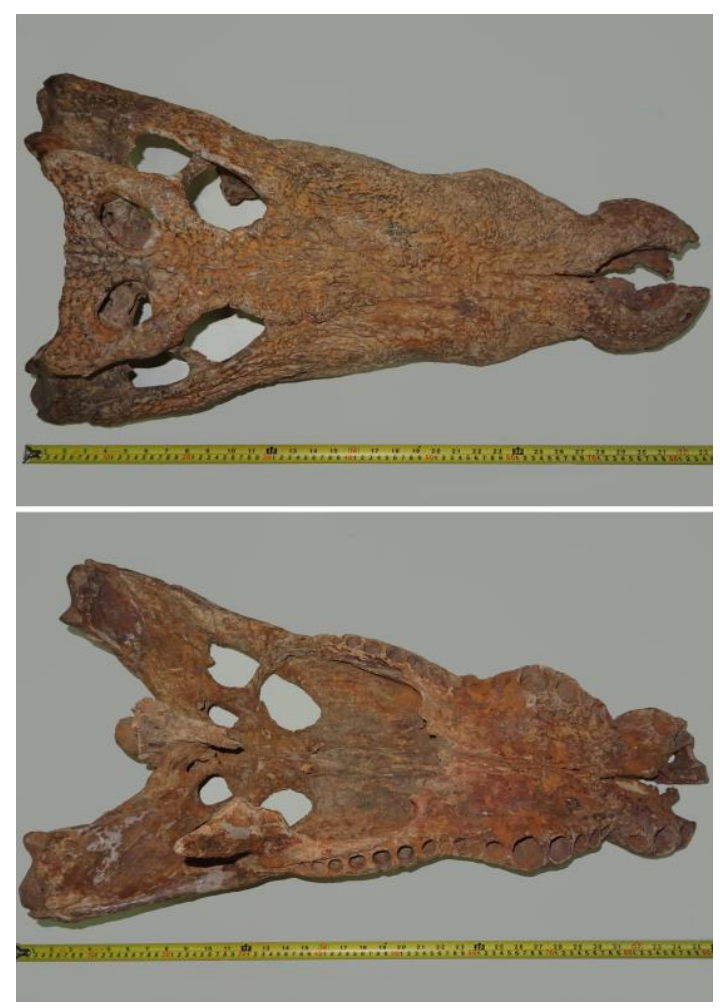

Figure 1. Dau Sau, the crocodile skull from Can Tho, with measuring tape from above (top) and below (bottom). Photo T. Ziegler

The man who discovered the crocodile skull did so when he was 86 years old. His family had worked as net fishermen at Dau Sau estuary for generations. His grandfather, who passed away in 1942, and his father, who passed away in 1965, told a story about a remote part of Dau Sau channel where big fish abounds, and where crocodiles "as large as two men" are found. His story continues that in the early years of the 20th century, there was a group of Chà people who were famous for hunting crocodiles. They helped to spear and kill a crocodile "as large as a five-plankboat" - longer than 6 meters - in the Cai Rang River. Therefore, after capturing the crocodile, everyone was cheerful, gathered around to divide up the meat. Mr. Ut also reported that up until around 1940 he still saw people butchering crocodiles upstream of the estuary. Crocodile meat was transported from Nam Vang and An Giang to Can Tho by boat (e.g., Can Tho Online 2010). At that point, this area had already been called Dau Sau estuary/Dau Sau channel. In area 1 (An Bình ward nowadays) there is still an ancient temple named ông Vàm Dau Sau [translated as sir Dau Sau estuary; people usually refer to big animals respectfully as ông (which means sir or grandfather)].

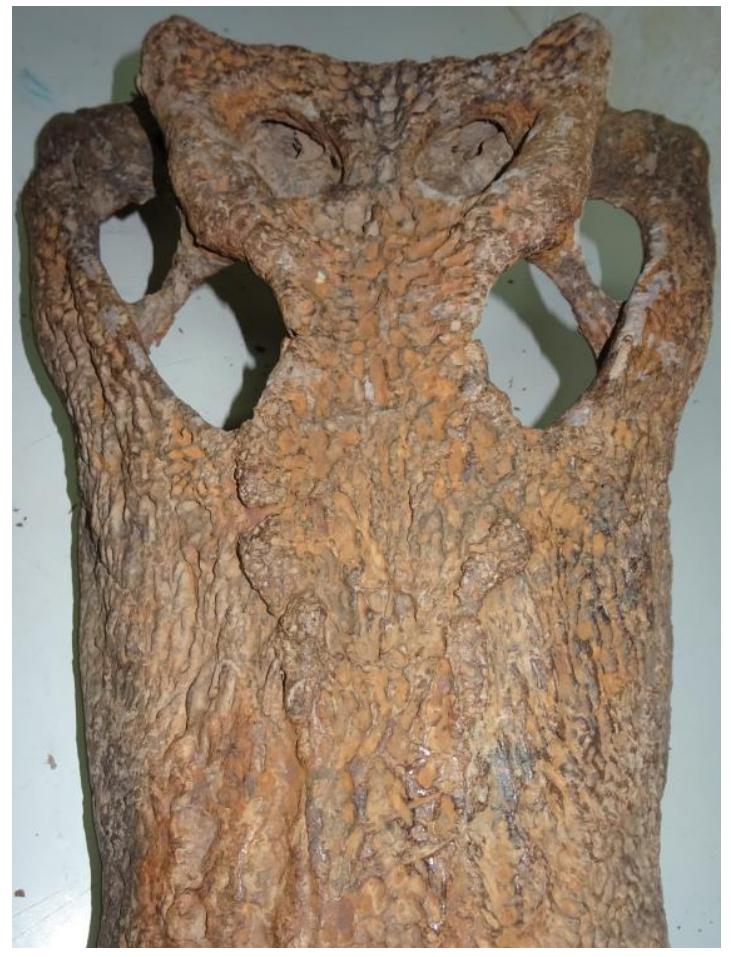

Figure 2. Two elongate ridges running from the orbits down the upper part of the snout are a characteristic of $C$. porosus and well discernible in Dau Sau, the crocodile skull from Can Tho. Photo T. Ziegler 


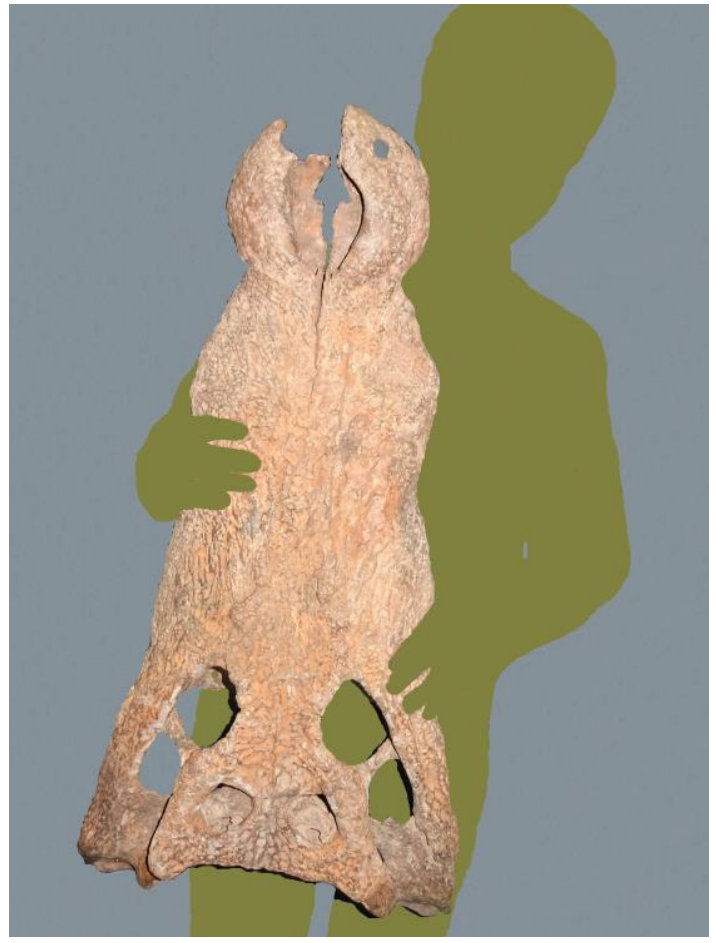

Figure 3. Held by one of the authors (Nguyen Thien Tao), the huge dimension of Dau Sau becomes apparent. Photo T. Ziegler

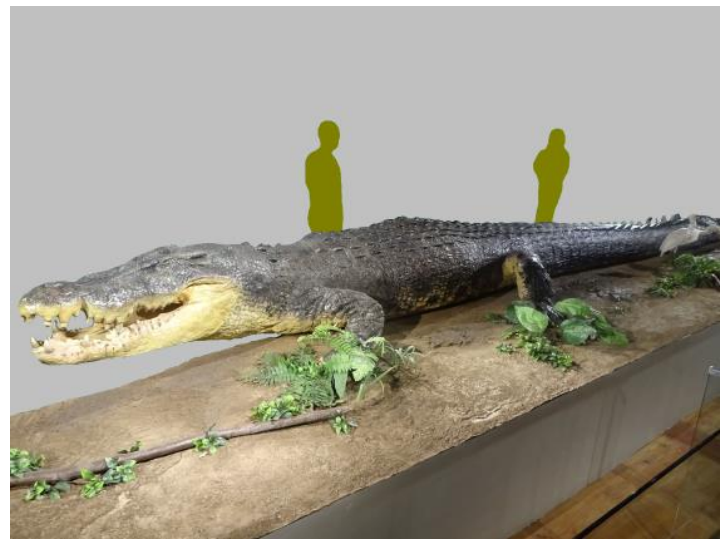

Figure 4. The Saltwater crocodile

(Crocodylus porosus) Lolong (6.17 m TL) in the public exhibit of the National Museum of the Philippines in Manila; for size comparisons see egrets at the right and adult visitors standing behind and observing the giant crocodile. Photo T. Ziegler

The skull is totally consistent with $C$. porosus. The possibility that it is a hybrid involving $C$. rhombifer can be rejected, because $C$. rhombifer were first imported in the 1980's. It also clearly predates crocodile farming in South-East Asia (from 1950's) and Vietnam specifically (1980's), where hybridization between $C$. siamensis and $C$. porosus is commonplace in captive animals. It seems unlikely that it could involve natural hybridisation in the wild with $C$. siamensis, but the possibility cannot be rejected as pending molecular analysis currently is underway.

Total length in $C$. porosus less than $5 \mathrm{~m}$ can be reliably estimated from head length (HL) alone, but the relationship between these attributes in large (> $5 \mathrm{~m} \mathrm{TL}$ ) C. porosus is more complex (Webb and Messel 1978). Fukuda et al. (2013) recommended a TL:HL ratio of 8.0 for $>5 \mathrm{~m}$ long C. porosus, and although this may be suitable for estimating size during population surveys, it does not take into account the variation that can occur among individuals. Definitive TL measurements are available for few large $C$. porosus skulls, but for five individuals reliable TL:HL ratios can be derived: 8.8 for Lolong $(6.17 \mathrm{~m})$; and, after adjusting for tissue loss (4\%; Webb and Messel 1978) between HL and TSL, 9.2 for Old Charlie from Australia $(6.15 \mathrm{~m})$ and Edgar from Java, Indonesia $(6.7 \mathrm{~m}), 8.8$ for Stuart from Australia $(6.7 \mathrm{~m})$, and 8.5 for Dhamara from India $(6.04 \mathrm{~m})$ (table 1). On the basis of these size ratios, the crocodile from Can Tho is estimated to be $6.3-6.8 \mathrm{~m}$ long.

Although slightly smaller than the largest known $C$. porosus skull $(76 \mathrm{~cm})$, from an individual killed in the early 1800s in Cambodia, and now held in the Natural History Museum, Paris (Whitaker and Whitaker 2008), Dau Sau, the skull from Can Tho, with a length of $70.7 \mathrm{~cm}$ certainly represents the largest known $C$. porosus ever reported from Vietnam and one of the largest C. porosus skulls recorded from anywhere in the world.

Acknowledgements: We thank Anna Rauhaus (Cologne Zoo, Germany), Jake Wilson B. Binaday (Crocodylus Porosus Philippines, 
Inc., Philippines), Grahame Webb (Darwin, Australia), Nguyen Vu Khoi (Wildlife at Risk, Vietnam), Nguyen Quang Truong (Institute of Ecology and Biological Resources, Vietnam) for providing information and various assistance. Thanks also to T. Pagel and C. Landsberg (Cologne Zoo, Germany) for their support of research and conservation activities in Vietnam. Cologne Zoo is partner of the World Association of Zoos and Aquariums (WAZA): Conservation Projects 07011, 07012, 10007 (Herpetodiversity Research, Amphibian and Reptilian Breeding and Rescue Stations, Siamese crocodile research and conservation). This research was partly supported by the Project BSTMV.8/16-19 to T. T. Nguyen.

\section{REFERENCES}

Britton A. R. C., Whitaker R., Whitaker N., 2012. Here be a dragon: Exceptional size in a saltwater crocodile (Crocodylus porosus) from the Philippines. Herpetological Review, 43: 541-546.

Can Tho Online, 2010. Văn hoá - Giải trí. Một vài suy nghĩ về địa danh Dau Sau https://baocantho.com.vn/mot-vai-suynghi-ve-dia-danh-dau-sau, accessed: 30/10/2010.

Fukuda Y., Saalfeld K., Lindner G., Nichols T., 2013. Estimation of total length from head length of saltwater crocodiles (Crocodylus porosus) in the Northern Territory, Australia. Journal of Herpetology, 47: 34-40.

Fukuda Y., How C. B., Seah B., Yang S., Pocklington K., Peng L. K., 2018. Historical, exceptionally large skulls of saltwater crocodiles discovered at the Lee Kong Chian Natural History Museum in Singapore. The Raffles Bulletin of Zoology, 66: 810-813.

Kar S., 2006a. Record of a large saltwater crocodile from Orissa, India. Crocodile Specialist Group Newsletter, 25(3): 27.
Kar S., 2006b. World's largest crocodile skull? Crocodile Specialist Group Newsletter, 25(4): 21-22.

Manolis C., 2006. Record of a large saltwater crocodile from the Northern Territory, Australia. Crocodile Specialist Group Newsletter, 25(3): 27-28.

Murphy D. J., Thuc P. D., Nguyen T. L., 2004. The Siamese Crocodile Reestablishment Programme in Cat Tien National Park, Vietnam, 1999-2004. Technical Report No. 48, Cat Tien National Park Conservation Project.

Platt S.G., McCaskill L., Rainwater T. R., Temsiripong Y., As-singkily M., Simpson' B. K. and Bezuijen M. R., 2018. Siamese Crocodile Crocodylus siamensis. In Crocodiles. Status Survey and Conservation Action Plan. Fourth Edition, ed. by S. C. Manolis and C. Stevenson. Crocodile Specialist Group: Darwin.

Polet G., 2002. Crocodylus siamensis reintroduced in Cat Tien National Park. Crocodile Specialist Group Newsletter, 21: 9-10.

Whitaker R., Whitaker N., 2008. Who's got the biggest? Crocodile Specialist Group Newsletter, 27(4): 26-30.

Webb G. J. W., Manolis S.C. Brien M. L., 2010. Saltwater Crocodile Crocodylus porosus. Pp. 99-113 in Crocodiles. Status Survey and Conservation Action Plan. Third Edition, ed. by S. C. Manolis and C. Stevenson. Crocodile Specialist Group: Darwin.

Webb G. J. W. Messel H., 1978. Morphometric analysis of Crocodylus porosus from the north coast of Arnhem Land, northern Australia. Australian Journal of Zoology, 26: 1-27. 